\title{
The Use of Energy Resources as Foreign Policy Tools: The Russian Case
}

\author{
A.Sait Sonmez, Assistant Prof. \\ Department of Political Science and Public Administration. \\ Faculty of Economics and Administrative Sciences, \\ OndokuzMayıs University, Samsun, Turkey \\ Sedat Cobanoglu, PhD Student \\ Department of Public Administration. The Institute of Social Sciences, \\ OndokuzMayıs University, Samsun, Turkey
}

doi: 10.19044/esj.2016.v12n11p78 URL:http://dx.doi.org/10.19044/esj.2016.v12n11p78

\begin{abstract}
The energy industry has an important place in the policies of Vladimir Putin, who became the president of Russia in 2000. During this period, Russia's economic and political power has increased through the rise of oil prices. Accordingly, Russia began to follow pro-active foreign policy on a global scale. "Energy Resources" used as a tool in foreign policy, are one of the dimensions of this proactive policy. In this study, how the energy resources are used in foreign policies of states is analyzed by the sample of Russia. Furthermore, the place of energy industry in the Russian economy and some of the outstanding companies operating in this industry are examined. On the other hand transportation policies (the energy corridors of Russia), performed inside and outside the country, are accompanied with some examples. Then, the role of energy is analyzed in the outputs of foreign policy followed by Russia.
\end{abstract}

Keywords: Energy Policies, Russian Foreign Policy, Oil, Natural Gas

\section{Introduction}

In the post-Soviet era, Russia left its ideology based polices and started to follow an approach which aimed to shift towards the liberal system. New reforms were added to the ones introduced during the era of Mikhail Gorbachev. In the period when Boris Yeltsin ruled, a privatization program was put into practice for a rapid transition from the planned economy to the market economy. A distorted economic structure occurred in this process by leading to the formation of a quite limited, but powerful capitalist class as well as indigent masses. Meanwhile, Russian economy 
found itself on the brink of the abyss when it faced with the Asian crisis (1997) (Sönmez, 2010: 39). During these years, the oil prices in international markets were quite low and this situation affected Russian economy adversely. Undergoing a restructuration process, the Russian state had to follow a passive foreign policy while trying to deal with its domestic problems.

From then on, Kremlin began to concentrate its attention on the energy policies. In the Soviet Union era, the income thatproducedby the energy industry had formed an important portion of the budget. However, the Soviet Russia used to make production on the basis of a planned economy and its technological potentiality. The oil and natural gas pipelines crossed over the former Soviet Republics and the former Soviet allies in the Eastern Europe were constructed in this era. Since the 1960's, the energy transmission lines were constructed into Western European states such as Germany. This situation became an important advantage for post-Soviet Russia, because it was able to export energy via these pipelines. Moreover, the other former Soviet Republics that used to compete with the Soviet Russia in this respect lacked this specific advantage. The routes of these pipelines were constructed in a way that would make the ex-Soviet republics and the east European countries dependent on Russia. But these pipelines were of old technology, thus they had a low productivity and a limited capacity for energy transmission. Therefore it was necessary to find new energy sources, to increase the production capacity of the current ones, to restore the energy transmission lines and to construct new ones. With this purpose in mind, the Russian state introduced a series of reforms which also aimed to attract foreign investors. Especially, privatization program was put into practice in order to increase productivity. Within the scope of this program, a limited number of the companies inherited from the Soviet Union were handed over to private companies and the rest of them to domestic ones. The magical formula which would boost the Russian economy was rediscovered: 'the energy industry'.

The economic and political transformation that Russia had been going through and its energy policies were supported by the primary representatives of the liberal system such as the United States of America (USA) and the European Union (EU). According to these Western powers, the ideological background of the Russian foreign policy that had troubled the Western world like a nightmare for almost seventy years could only be changed through the integration of Russia into the liberal system. Therefore, the economic and commercial relationships between the West and Russia had to be consolidated and a 'inter dependence' should be established. Enriching Russia would integrate into the liberal economic system much more andbecome a feasible market for the Western world. Having been 
dominated after the Second World War, Japan and Germany were also 'tamed' through similar methods after all.

Vladimir Putin, having come to power in 2000, accomplished some reforms in the economic and political domains. Among them, there are renationalization of some strategically important institutions and the termination of the sultanate of oligarchs. What Putin aimed to do was to make it possible for the Russian economy to grow at least two times more than the Western economies annually. Therefore, he concentrated on the energy policies. It is important to mention at this point that Putin wrote his dissertation on the issue of 'foreign policy on the basis of energy' (Onay, 2007: 279-281). Since Putin came to power, the oil prices has increased in the global energy market, the pipelines that started to be constructed in the Yeltsin period have been completed, additional trade agreements have been concluded in the domain of energy and thus the share of the energy industry in the Russian foreign trade has increased. As a result of all these developments, the Russian economy has made a rapid developmental move. To express this development in figures:

The high inflation in the Yeltsin period has stopped; wages and the purchasing power of ruble have increased. While the per capita income was 2.270 dollars in 2000, it reached 9.700 dollars in 2002 and almost 13.000 dollars in 2007. By the year of 2008, Russia has grown approximately by $8 \%$ every year, paid its internal and external debts and increased its foreign exchange reserves to 280 billion dollars and its gold reserves to 400 tones. Thus, it has got rid of its dependency on the International Monetary Fund (IMF) and the per capita income has gone up by about six times (Sönmez, 2010: 46).

The four big countries which have developed the most in the recent years are defined as BRIC, representing the initials of Brazil, Russia, India and China, respectively. While the Western economies were traumatized by the global financial crisis in 2009, Russia appeared as an economic and political power again on a global level. Economically empowered Russia started to challenge the Western powers. The crises in Georgia, Ukraine and Syria show that Russia will not be hesitant to use force for its own interests "despite the West'. After the annexation of Crimea, Putin announced that 'the uni-polar system has come to an end" (Kavkaza, 2014: www.prisonplanet.com).

The main theme of this study is based on the analysis of the energy policies underlying Russia's economic and political rise that has been outlined above. In other words, this study interrogates what kind of 
developments energy resources might trigger in the process of their empowerment in the foreign policies of states by focusing on the Russian case. This study will also attempt to explain why Russia, which utilizes the energy industry as a political tool in its foreign policy, features the role of energy via its carrot or stick policy and what kind of players and factors take part in this process. In brief, the study will discuss the nature of the relationship between the energy policies and the foreign policy of Russia.

\section{The Energy Card as a Foreign Policy Tool}

States, especially the great ones, make use of non-military methods to increase their economic and political power, shape foreign policies of other states in line with their own interests and create a sphere of influence in this way. The most widespread form of these methods is the use of economic factors as a foreign policy tool. Sometimes great state powers attempt to shape foreign policies of small countries through the method of foreign assistance. And sometimes they punish the small countries whose foreign policies they disturbing by activating such tools as embargo and boycott. Thus, it becomes possible for powerful states to have an impact on or govern the moves of dependent states through certain foreign policies. From this perspective, it is impossible to argue that the economic steps that governments take can be free from political targets. The reason that certain states choose to use their economic and commercial relationships as a foreign policy tool may be explained on the basis of three conditions (Ar1, 2011: 411-417):

1. Make some promises to the dependent state by taking advantage of its needs and subordinate situation or threaten it economically,

2. Take hold of rich natural resources and deprive rival states of them,

3. Create a sphere of influence by forming economic satellites and relationships.

In this context, countries that have rich energy resources may give privilege subordinate states in some respects (through a rewarding method) or impose certain sanctions on dependent states, and thus shape their foreign policies in a way that will be advantageous in terms of their own national interests.

Energy resources have a special place among the economic factors that are used as a foreign policy tool. Hydrocarbon resources have strategic significance and are found only in a limited number of countries in the world. Therefore, certain countries that have rich hydrocarbon resources such as natural gas and oil are able to transform these resources into a foreign policy tool. The first example that comes to mind in this respect is the oil shocks in 1973 and 1974. Because of the crisis started by the Organization of Arab Petroleum Countries (OAPEC), the price of crude oil 
per barrel, which was 13.61 dollars in 1972, increased by about four times and reached 53.94 dollars in 1974 (Darmstadter, 2013: 4). The oil shocks had many internationally important economic and political consequences. Those countries that had started the crisis had a certain economic welfare. However they were not among the greatest states in the world. Even so, they were able to affect the economic and political atmosphere of those countries that were more powerful than OAPEC states but dependent on foreign energy resources such as the USA, the United Kingdom, Japan and France. The oil shocks also affected 'not only the Arab-Israeli conflict, but also the Cold War, relations within the European Economic Community (EEC), relations between the EEC and the United States, referred to as the North-South dialogue' (The October 1973 energy crisis, https://networks.h-net.org :1).

Although certain economic tools were used in the oil shocks, the prime mover of the crisis was actually political. The oil card was put into action in the hope to deter the countries which chose to follow a pro-Israel policy in the Arab-Israel war from this attitude. During the 1973-74 ArabIsrael war, the Arab countries separated third-party countries into three groups on the basis of their foreign policy regarding the war: the pro-Arab (friendly) countries, the pro-Israel countries and the neutral countries. And the oil card was used in three different ways in the face of these countries. The friendly countries did not suffer from any oil cut; however, neutral countries had to deal with it. The pro-Israel countries, on the other hand, were faced with an embargo (Ülger, 2002: 150). After the crisis, the EEC started to follow a pro-Palestine policy and mentioned the rights of the 'Palestinian people' in the summit organized in December 1973. In 1975, the EEC countries declared that the 'Palestinian people' had a right to express their 'national identity' and this might be possible only if Palestinians could reach their legitimate rights, including 'their homeland'. Another important step that the EEC took in this respect was to issue the Venice Declaration in 1980. The Venice Declaration mentioned Palestinians right of 'selfdetermination' (Ülger, 2002: 151-152). The EEC continued to follow a proPalestinians policy during and after the Madrid Conference (see Ülger, 2002: 153-156).

The developing countries that are dependent on foreign energy resources were affected much more adversely by the oil shocks, therefore the welfare difference between the North and the South started to increase from then on. In addition, in 1974, the General Assembly of the United Nations, which was dominated by the developing countries then, granted the Palestine Liberation Organization the observer status and declared that 'Zionism is a form of racism and radical discrimination' in 1975 (https://en.wikipedia.orgc). 
The oil card can also be used in order to influence the foreign policies of the countries that export oil. In the 1980s, when the Second Cold War just started, certain petroleum exporting countries such as Saudi Arabia pumped an excessive amount of oil and thus caused a decrease in the oil prices in the global markets. One of the reasons that the Soviet economy went bankrupt in the Gorbachev period was argued to be this decrease in the oil prices. In 1985, the oil prices in international markets saw the lowest levels since the Second World War(Purtaş, 2005: 4). Similar policies are still being followed today due to the encouragement of Washington, which is disturbed by Putin's policies. The Russian economy was affected particularly adversely by the decrease in the oil prices. It is necessary to point out that while the oil prices are determined in and through international markets, the natural gas prices are agreed upon through bilateral agreements concluded between exporter and importer states. Moreover, while oil is generally transported via tankers, natural gas is mostly transmitted through pipelines. Hence, bilateral agreements came into prominence and the exporter countries usually become the advantageous party. Therefore, it is not surprising that Russia especially makes use of the natural gas card effectively in its foreign policy.

There are various claims regarding Russia's energy policies. For example, Russia's official documents state that the main target of the energy policy is the Russian domestic policies. According to the Russian governmental decree, Russia's energy policies concerning fossil fuel which has been exporting to many countries in Asia and Europe aims to utilize natural energy resources at a maximum level, create a sustainable economic growth, increase the life standards of the Russian citizens and consolidate the Russian economy (Rasporyajenie No: 1715R, 2009). It has been argued that Russia makes use of its oil and natural gas exportation as a political tool, i.e. as a power mechanism, especially in the face of the former Soviet countries. We can conclude from these arguments that Russia attempts to increase its power and influence by using energy as a fundamental tool (Houtari, 2011: 121).

As can be seen in the following part of the study, attempts to be a monopoly in the energy domain of the former Soviet geography, Russia uses the energy factor in its foreign policy in three different strategic ways:

1. Importing the energy resources in the former Soviet Republics at a discount and exporting them to other countries for higher prices.

2. Following a carrot or stick policy for the countries which have come to be dependent on the Russian energy and trying to shape their foreign policies for Russia's own national interests.

3. Ensuring that the routes of the pipelines cross over either its own territories or the ones of the friendly countries. 


\section{Russia's Energy Resources}

Russia is one of the largest oil-rich countries in the world. Russia can be said to be in a leading position in this respect since its energy resources are not only intense, but also diverse, which means that it harbors many extra energy resources. Therefore, it is one of the biggest energy suppliers in the oil and natural gas industry both as a manufacturer and as a seller. Hence, energy policies come into prominence for Russia (Chernitsina, 2015: 3). Russia is on the first, second and eighth rank in terms of the proven natural gas, coal and oil reserves, respectively in the world. Russia has $32 \%$ of the proven natural gas reserves, $10 \%$ of the explored coal reserves, $12 \%$ of the proven oil reserves and $8 \%$ of the proven uranium reserves in the world (en.wikipedia.org-a). In this part of the study, the situation of the oil and natural gas industries, which are the backbone of the Russian economy, will be analyzed. In 2013, nearly half of the federal budget and 68\% of the export revenue were obtained via these two industries(US Energy Information Administration, 2015: 13).

\section{The Natural Gas Industry}

The importance of natural gas has been increasing day by day in the global energy market. The reason behind this is that natural gas can be utilized in various areas and the demand has been constantly increasing. According to some experts, the demand for natural gas will be going on increasing annually by $1.7 \%$ in average and reach $4.75 \mathrm{tcm}$ in 2035 . The gas consumption is expected to catch up on the coal consumption in time and it is predicted that the natural gas industry will play a key role in the energy markets in the future (WEO, 2011: 155). It is known the fact that Russia has the biggest natural gas reserves in the world and is one of the biggest suppliers in this respect. It ranks second in the world as a dry natural gas producer. Although many Russian companies have been increasing their natural gas production, Gazprom continues its domination as a state-backed company. According to the report issued by the US Energy Information Administration (EIA) on January 1, 2015, as seen in Table 1, Russia has the biggest natural gas reserves with 1.688 trillion cubic feet (tcf). According to 2011 data, the flared natural gas reserve in Russia is approximately 1.300 billion cubic feet (US Energy Information Administration, 2015: 11-13).

Although Russia has the biggest natural gas reserves in the world, but it is noted the top of the list in production and exportation. As can be seen in Table 2, Russia was the biggest natural gas producer in the world between the years of 1992-1998 and of 2003-2008, however it has lost this title to the USA in the recent years. According to the data provided by the International Agency, while the USA produced 689 billion cubic meters natural gas in 2013, Russia produced 671 billion cubic meters. The Russian natural gas 
production corresponds to $19.3 \%$ of the total natural gas production in the world (en.wikipedia.orb-b). Notwithstanding, such companies as Gazprom and Novatek tend to increase their production. Moreover, certain oil companies in Russia want to enter the natural gas sector (US Energy Information Administration, 2015: 12).

Russia started to export natural gas in the era of the Soviet Union. It entered into eight 'gas-for-pipe' agreements with such countries as West Germany, France, Austria and Italy between the years of 1968-1975. According to these agreements the Soviet Union would sell natural gas to these countries in exchange for natural gas and pipeline equipments. Moscow started to export natural gas to the Western Europe for the first time in the 1970s (The Soviet Gas Pipeline in Perspective, 1982: 17). In the next years, a dependency relationship may be argued to have emerged between the EU and Russia with more agreements to have been concluded. The income generated in and through the natural gas exportation became an important item over time in the Russian economy. In 2013, natural gas constituted $14 \%$ of the total revenue that Russia generated through exportation. With the decreasing trend in the natural gas consumption in the Western Europe as of the mid 2000s, Russia developed a new strategy to diversify its natural gas market and started to sell liquefied natural gas to Asian countries. In 2014, Russia tended towards the East upon the sanctions imposed by the USA and the EU. In the same year, Russia and China entered into an agreement to construct two pipelines between them. This agreement also aims at an annual 2.4 tfc natural gas trade between the two countries (US Energy Information Administration, 2015: 13).

\section{The Oil Industry}

According to January 2015 data, Russia has 80 billion barrels proven oil reserves (www.cia.gov). As seen in Table 3, The production and exportation figures show that Russia ranks among the top three in the world in this respect. In 2014, it was stated that Russia was 'the world's largest producer of crude oil (including condensate)' and 'the third largest producer of petroleum and other liquids (after Saudi Arabia and the United States) (...) with average liquids production of 10,9 million barrels per day (b/d)' (US Energy Information Administration, 2015: 1). Russia is the second largest crude oil exporter after Saudi Arabia. In 2014, while Russia exported 152.6 billion dollars of crude oil, Saudi Arabia reached to 268.2 billion dollars of crude oil exportation. Russia's export quantity corresponds to $10.5 \%$ of the total crude oil trade in the world (Workma, 2016: www.worldstopexports.com). In 2013, the revenues from crude oil and products formed 54\% of the Russia's total export revenue (US Energy Information Administration, 2015: 7). 
Similarly, in the era of the Soviet Union, the oil revenues formed an important portion of the economy. In the 1970s, almost one quarter of all the oil production used to be exported. This corresponded to a daily average of 900.000 barrels of oil (The Soviet Gas Pipeline in Perspective, 1982: 17). In the post-Soviet era, importance of the energy industry increased. As indicated below, while the national borders shrank in the post-Soviet era, the amount of production increased hugely. It is possible to analyze the oil production and exportation process in the post-Soviet era in three periods. In the first period between the years of 1990-1996, the oil production decreased from more than 10 million barrels to less than 6 million barrels. During these years, the production faced with an annual degradation by $9 \%$ in average. This situation was one of the factors that would lead to the collapse of the Russian economy. The second period between the years of 1999-2005 dressed the wounds of the Russian economy. During these years, the global price of oil per barrel increased from 18 dollars to 55 dollars. In accordance with this development, the annual production increased by $7.5 \%$ in average. This situation accelerated the Russian economy and created extra sources of income in the Russian private sector. In the third period between the years of 2005-2014, the annual production decreasingly grew by $1.3 \%$ in average. The reason behind this deceleration was interpreted through the term of 'Low Hanging Fruit'. It means that Russia attained a rapid success without making much effort to reach its goals. Another fundamental reason behind this deceleration was the transition from privatization to nationalization (Henderson, 2015: 4).

\section{Dominant Actors in the Russian Energy Industry}

The prominent energy companies in Russia are influential both in the determination of the Russian national interests and in the formation of Russian foreign policy. A significant number of these companies are under the state control. Particularly some big companies such as Gazprom have been affecting government policies in many areas, foreign policy being only one of them. Thus, in this part of the study, companies that affect both the economic and the political life of Russiawill beanalyzed briefly.

\section{Gazprom}

As a state-connected company, Gazprom is one of the biggest energy companies in the world. As for the estimates by British Petroleum (BP), Gazprom has $16.5 \%$ of all the gas reserves in the world. Gazprom carries out $84 \%$ of the total gas production in the Russian Federation, and $19.4 \%$ of the total gas production in the world. In addition, Gazprom is the only user of its pipelines which transport the gas across the global market (Mitrova, 2008: 2). It is possible to state that Gazprom is the biggest company which serves 
the political and economic purposes of the Russian state. As a dominant actor in the gas industry, Gazprom has been strengthened more by Putin under the state control. The Russian state holds $51 \%$ of the shares of the company (Finon and Locatelli, 2007: 4).

\section{Rosneft}

Rosneft is the leading company in the Russian oil industry and the biggest publicly-traded oil company in the world. $40 \%$ of the yearly oil production in Russia has been carried out by Rosneft. "Rosneft is a global energy company with major assets located in Russia and a diversified portfolio in promising regions of international oil and gas sector, including assets in 18 states in America, Asia and European continents. "Rosneft's corporate activities include exploration, development, production, sale of oil and natural gas, refinement of crude oil and transportation and sale of petroleum products. These activities have been efficiently carried out at home and abroad. Rosneft is one of those companies which have a strategically important position. The main shareholder is OJSC Rosneftegaz with a $69.50 \%$ of the shares. And this company is $100 \%$ owned by the state. As for the other shareholders, BP holds $19.75 \%$ of the shares and the remaining part is public shares (Rosneft, 2015: www.rosneft.com).

\section{Transneft}

As a petroleum pipeline company, Transneft has the biggest system for petroleum transportation in Russia and the longest petroleum pipelines in the world. Transneft transports approximately 420 million tons of crude oil every year through its $80.000 \mathrm{~km}$ pipelines stretching between Siberia and the Baltic. Transneft has 400 pumping stations, 1000 storage facilities and 35 refineries in 101 regions (ICONICS, 2010). The corporate governance in Transneft has some state representatives, too. Transneft is significantly influential in the determination of projects and strategies regarding petroleum pipelines (http://en.transneft.ru).

\section{Lukoil}

Lukoil is one of the biggest oil and gas companies in the world. More than $2 \%$ of the total crude oil in the world is produced by this company. Lukoil possesses approximately $1 \%$ of all oil reserves in the world. $16.4 \%$ of the total crude oil in Russia is produced by Lukoil and $15.7 \%$ of this production is processed (refined) in Russia. Lukoil is the biggest company in which private sector takes part. According to the figures of 2014, Lukoil's annual revenue is approximately 144 billion dollars (www.lukoil.ru).

As influential actors in the global energy markets, these companies can be used as a political and economic tool for pressure within the scope of 
the Russian foreign policy. Having been rapidly privatized after the dissolution of the Soviet Union, these companies entered a period of expropriation in the 2000s. Therefore, it is possible for the Kremlin to use these companies, which have already been run by the state, directly in the policies regarding the other nations.

\section{The Energy Corridors of Russia}

Apart from exporting the natural gas and the oil that has been drilled from its own territories via transportation systems, Russia also transports the energy resources of some of the former Soviet republics to international markets through the pipelines. Therefore, Russia is able to manipulate the countries whose energy resources it transports and has an indirect right to comment on the decisions regarding these resources. Thanks to this interventionist policy, Russia is also able to influence the global oil and natural gas markets to a considerable extent. It is possible to say that Russia has an advantage in this respect, because of two significant issues: First, during the Soviet era, the pipelines that transported the oil and the natural gas resources from the Central Asia and Caucasus were constructed to cross over the Russian territories. In this way, interdependence occurred between Russia and these countries. Second, the pipelines that transported energy to the Eastern Europe had to cross over the Russian territories due to the geographical necessities. Therefore, Russia gains a strategic advantage in the face of its opponents thanks to the pipelines inherited from the Soviet Union. After all, constructing new pipelines is an extremely expensive endeavor. Another strategic advantage of Russia stems from its geographical magnitude. Being the neighbor of continents and countries that import energy such as Europe, Japan and China is a great advantage for Russia. Therefore, as part of its energy policy, Russia has been trying to realize new pipeline projects (www.gazprom.ru-b), which can be seen Table 4 and Table 5.

Russia has wide range pipelines network. Thus this country can easily affect the other countries using energy policy. For example, as can be seen above at Table 4 that Russia has gain power because of the crude oil pipelines both western and eastern areas. Russia's energy policy not onlycontains crude oil pipelines but also natural gas pipelines. Both of them for Russia are so vital dynamics to affect the foreign policy and correlations between countries where is related with Russia about energy requirements. These relations dated back to Soviet era. Moscow's energy exportation was began during the Soviet era. First, in the 1940s, the Russian gas was exported to Poland, although in small quantities. 3.4 bmc (billion cubic meters) natural gas that was sold to Europe reached 26 bmc in the 1970s and 1980s, and then $109 \mathrm{bmc}$ in the 1990s (Stern, 2005: 1). 
After the dissolution of the Soviet Union, Russia constructed many pipelines for energy transportation and thus took part in the global market. As can be seen in Table 4, Russia has been increasing its maneuverability in the foreign policy by conducting new projects. For example, it attempts to head not only for European countries or former Soviet republics, but also for new markets such as China within the scope of different projects such as Siberia -2 . Being in the need of 94-106 bmc natural gas by the year of 2010, China seems as becoming new market for Russia (www.gazprom.ru-c, 2016). Russia has such a big geographical place that it can control energy policies on a few continents. It can be stated that both Europe and Asia are under control of Russia in the context of oil and natural gas pipelines. As can be seen at Image 1 Russia has a so complex pipeline network. In this context, one example from each category of the pipelines will be chosen that Russia has been using as a tool in its foreign policy and expand the subject matter in this respect.

\section{The North Stream Project}

Most of the gas flow between Europe and Russia used to cross over Ukraine and Poland. However, Gazprom started to search for new alternatives due to the problems occurred bythe time between Russia and these countries within the context of foreign policies. One of these alternatives is the North Stream Project (Chyong et al., 2010: 2). The North Stream project was first brought to the agenda in 1997 and officially put into practice on April 24, 2001. The need that Germany, Holland, France, Denmark and the UK have for natural gas is the primary reason behind this project (Baytekin, 2010: 134).

\section{The South Stream Project}

The southern corridor of the natural gas transportation system will supply the central and southern parts of Russia with additional volumes of natural gas. It means that the Russian industrial units and municipal services will develop in the regions through which the southern corridor passes. The South Stream Project will also step up gasification rates and secure uninterrupted gas supplies into the Turkish Stream. The total length of the gas transmission system will be 2,506.2 kilometers. The project involves ten compressor stations with a total capacity of $1516 \mathrm{MW}$. Once the southern corridor gas pipeline system is put into practice, it will transport $63 \mathrm{bcm}$ natural gas every year. The project has been planned to be completed between the years of 2010-2017. The line in question covers approximately 8 regions in the Russian territory. These are Nizhny Novgorod, Penza, Saratov, Volgograd, Voronezh, Rostov Krasnodar and the Republic of Moldova (www.gazprom.com). In addition, energy which comes from Russia will be 
carried into Central and Southern Europe by the Southern Stream Project (http://www.iefe.unibocconi.it/).

\section{The Natural Gas Pipeline of Yamal - Europe 2}

The fundamental purpose of this pipeline is to transport the $4 / 5$ of the natural gas that is drilled from the Russian territory over Ukraine and the remaining 1/5 over Belarus to Europe. Starting from the Yamal Peninsula, the line reaches Germany through Belarus and Poland by passing through approximately 4000 kilometers. Before the crisis arisen between Russia and Ukraine, the pipeline of Yamal - Europe 2 was actually intended for another route which would transport the Russian natural gas to Austria and Italy through Poland and Slovakia. In addition to the Ukrainian crisis, Russia and Poland could not agree upon the construction of the second part of the line. Following these developments, Russia began to concentrate on the northern pipeline instead of this project. According to Gazprom, the northern pipeline project will generate more economic profit anyway. In the meanwhile, Russia will be giving an answer to the inconsistent behaviors of Poland (Erbil, 2010: 112).

\section{The Role of Energy Industry in the Russian Foreign Policy}

Since the Soviet era, Russia's energy policy has been based on the oil and gas industry. In the 1970s, the Soviet Union used to produce about 1 billion tons of oil every year. In this period, Moscow pursued a politicallyweighted energy policy regarding the third world and the other republics in the Soviet Union. Moscow's energy trade with capitalist countries, on the other hand, was based on pragmatism with the purpose of making economic profit in mind (Sudo and Kazankova, 1998: 1-10). Today the Russian oil and natural gas industry has become a key actor especially in the European and Asian market. As indicated before, it is the Russian government that has laid hands on these industries. In addition, the increasing influence of the people who had key roles as intelligence officers in the Russian political life has also increased the effectiveness of the state in this process. It has been claimed that the Russian companies follow a policy which includes the purchase of key energy fields, storage centers and pipelines in the Central and Eastern Europe. After the dissolution of the Soviet Union, Russia may sometimes remove subsidies and increase natural gas prices within the scope of its energy policies regarding the former Soviet republics. This also changes the prices in the global market (Woehrel, 2009: www.fas.org). Hence, Russia’s energy policies may change natural gas prices in the global markets.

Russia follows certain methods which are similar to the global policies carried out by the USA. In the post-cold war era, the USA has 
followed a foreign policy strategy based on some economic, political and other precautions in the face of its opponents that have a geo-economically important position such as China, Russia, India and Germany. The biggest opponent of the USA in terms of military capacity and energy resources is Russia. The global economic crisis that may arise at this point limits the increase of the quantities demanded from the energy suppliers. In the 1970s and 1980s, the USA followed a policy which included the changes in the oil prices and in the pipeline roots that it used to transport energy resources. This policy had an impact on the dissolution of the Soviet Union. Today Russia has been using similar methods (Ageev and Loginov, 2014: 33). Since the 2000s, there has been a mutual relationship between the Russian energy policy and the energy prices in the global markets. The increasing energy prices have permitted to Russia to grow more powerful and more proactive in its foreign policy. The severity of the problems that Ukraine and Georgia have been recently challenging with can be given as an example to this situation. Today the Western World faces an enormous corporate state, that is, Russia. This corporate state draws its power from fuel oil and natural gas. Governed with a semi-authoritarian system with geopolitical goals, Russia is able to use its political alliances as well as its natural gas and oil reserves. Gazprom emerges as the most important tool for the foreign policy at this point (Goldthau, 2008: 53-54).

Russia has been following these strategies in order to be an energy monopoly in the former Soviet geography(Telli, 2015: 356-357):

1. Maintaining its monopoly on energy supply,

2. Preventing foreign energy companies from controlling the Russian and the Central Asian energy areas and having a role in production and transportation,

3. Determining policies not to let foreign gas producers enter the European market,

4. Acquiring shares of foreign gas producers in order to be able to influence their sales policy.

Russia uses the energy factor at its hand as a repressive tool in various ways particularly for the former-Soviet republics. For example, Moscow may sometimes cut off the energy flow on the basis of certain political factors, but claims that the decision is based on "technical problems". Natural gas and oil companies with a monopoly power such as Gazprom serve not only as an economic tool, but also as a political tool for pressure. Some poor countries have become dependent on Russia especially in terms of natural gas and oil. InNygren's words,using energy as a politically striking weapon, Russia tries to strengthen its hand during negotiations and political discussions by cutting off the natural gas and oil flow to these countries (Kanet, 2008: 9). 
It seems necessary to point out that post-Soviet Russiaactually has a limited number of tools from which it can benefit in its foreign policy. These "limited" tools determine the nature of relationships that Russia establishes with the former Soviet republics and European countries and how it behaves to these countries. Moscow attempts to use its energy card and thus realize its economic and political projects. Among Russia’s political projects are to establish customs and states unions with its strategic partners, establish military bases in the strategic regions of these countries, support allies and weaken enemies. Russia's primary economic goal is to increase the income that it has been gaining from energy sales. "This means reducing exposure to transit countries that can hold Russian energy sales hostage, forcing all customers to pay a market-based price reflecting EU price levels, increasing ownership and control of energy infrastructure, and expanding access to high-profit markets.” However, Russia can sometimes be torn between its economic and political projects. In such situations, Kremlin has hard times to make a decision between two domains. "Thus, Russia is sometimes willing to sacrifice economic gain to assert political advantage, and vice versa" (Orttung and Overland, 2010: 74, 75).

Russia has used the energy card particularly effectively under period of Putin's governments. As mentioned before, during the first years of Putin's government, the energy prices increased on a global level and Russia increased its energy exportation. These two factors enabled the Russian economy to gain a developmental speed. Putin's government tries to sustain this economic development and restore Russia's power as in the cold war era. Another goal that Putin's government sets for itself is to increase Russia's influence in the Central and Eastern Europe, Caucasus and the Central Asia. However, some outstanding authorities such as Andrey Illarionov, the economy advisor of the Kremlin, do not support the idea that Russia should use its energy resources as a weapon in its foreign policy. What is behind this argument is that such foreign policies will actually damage Russia’s own energy system in the long term (Smith, 2008: 4).

As mentioned above, Russia continues to use the energy resources as the most important instrument in its foreign policy. It has even determined a series of principles regarding its energy policy. In this context, a study suggests that the current Russian government has already been planned its energy policies that it will pursue up until 2020. The fundamental strategies that the Russian government has adopted in its energy policies are as follows:

- To ensure energy security

- To use energy effectively

- To form an effective budget

- To ensure the ecological security of energy 
Russian government itself shapes the fundamentals of the Russian energy policy strategic goals of which are given below.The use of underground sources; the management of funding of these sources; the development of fuel and energy resources in the domestic market; the evaluation of the role of energy in the regional and foreign policy; and social, scientific, technical and innovative policies are all analyzed within the scope of the energy policy of the Russian state. And the basic factor here is the role of economic regulations (in terms of prices, taxes, customs and market economy) (Rasporyajenie1234P, 2003).

\section{Three Important Strategies That Russia Uses in its Energy Diplomacy}

There are some parameters that determine how Russia is able to use its energy factor effectively within the scope of its foreign policy. While one of them is the fact that Russia imports cheap natural gas and oil and exports them for a higher price, another parameter is the carrot and stick method that Russia uses in the price negotiations with the countries that can be said to be dependent on Russia. Finally, Russia can choose to change the routes of its natural gas and oil pipelines if it has to follow a security policy or adopt a particular strategy.

\section{Strategy towards the Central Asian and Caspian Basin Energy Resources}

Russia’s energy policies are generally analyzed as having two phases. The first phase represents the time period before 2010, and the second phase is the time period after 2010. In the first phase, Russia tried to consolidate its economy and improved its infrastructure in order to have a say in the energy markets. Although the price of natural gas was increased, various programs were planned in order to struggle with the socio-economic shrinkage that would come about with the increased price of natural gas. Ranging from drilling energy resources to selling them, many reconstruction projects were carried out in this period, as well. In the second phase, the production has increased more than $1.5 \%$ together with the infrastructural works; in addition, various policies have been designed in order to construct transportation systems to transport energy effectively (Rasporyajenie 1234P, 2003: 38-41). In other words, Russia attempted to complete its reconstruction process by using cheap energy resources in the first phase, and it started to follow an active policy in terms of energy in the second phase. Russia pursued a relatively passive foreign policy in its reconstruction period until 1998.

While Russia had a high income on the basis of energy during the Soviet era, not only Russia but also Kazakhstan, Azerbaijan and Turkmenistan started to have control on the natural gas and oil reserves in 
the Caspian Sea region in the post-Soviet era. Having difficulties even in paying its debts in the beginning, Russia attempted to organize and be influential in the energy policies of Kazakhstan and Turkmenistan. Although certain multinational companies started to dominate the Caspian Sea region in the midst of the 1990s, Russia was advantageous anyway mainly due to the fact that it had long and organic relationships with these nations and that the transportation system had been made by Russia itself (Bilgin, 2005: 47). Hence, as per the energy policy that it followed up until 2010, Russia preferred to obtain cheap natural gas and oil from the former-Sovietrepublics and sell these energy resources in the European market with the price rate that itself determined.

However, the pricing policy that Russia has been implementing for the energy resources of the countries in the Caspian Sea region affect the energy security of the EU in a negative way. First of all, Russia buys natural gas from these countries for a cheaper price and then sells it in Europe for higher prices. Second, Russia uses the gas that has bought from the Central Asia in the domestic market and thus the domestic consumption of energy resources gets relatively cheaper. Russia also sells the gas that has drilled from its own territories in Europe for similarly higher prices. Third, Russia makes Gazprom's firms such as Itera, EuralTransGas and RosUkrEnergo richer by selling the Turkmen gas to Ukraine (Socor, 2008: 75-76). Since Gazprom remained incapable to meet the gas requirements of the Western Europe and Turkey, Russia needed and tended towards the Turkmen gas (Soltan, 2001: 185). Moscow was very well aware of the fact that Ashgabat was dependent on it due to the energy routes crossing over the Russian territory, thus used to cut off the gas at different times or did not pay its debts to Turkmenistan by alleging its credits to the countries that it sold the Turkmen natural gas such as Ukraine. In 1997, Russia demanded a higher transportation fee for the pipeline and negotiated with Turkmenistan to lower the natural gas price (Purtaş, 2005: 212). As a result, Russia managed to purchase the Turkmen gas for a price that was only one third of the international price and sell it for its normal market value, thus generated an income from the gap between these prices (Baycaunova, 2000: 260).

Putin has entered into new agreements with Kazakhstan and Turkmenistan regarding the domain of energy. According to the agreement between Turkmenistan and Gazprom in October 2006, Turkmenistan would annually sell Russia 50 million cubic feet of natural gas and take 100 dollars for each 1.000 cubic meter. This was approximately 50\% more than the price that Russia used to pay before. However, Gazprom was selling natural gas for 235 dollars to the West European states in the same period. Russia also concluded a joint venture agreement with Kazakhstan; within the scope of this agreement, the natural gas drilled from Karachaganak region, would be 
processed by Gazprom and transported to the European market through the Russian territories. In 2007, the line that transports the Turkmen and Kazak gas to Russia (through Uzbekistan and Kazakhstan) was improved. Hence, the gas transportation was activated from the Central Asian countries to Russia (Telli, 2015: 185).

\section{The Carrot and Stick Policy}

Russia's Carrot and Stick policy constitutes risk for some of the former Soviet Republics. This risk concentration stands out particularly for Belarus, Ukraine, Moldova and Georgia. After the dissolution of the Soviet Union, these countries became dependent on Russia. Russia cuts hydrocarbon fuels of these countries partially or for a short period of time, which constitutes a foreign policy medium Russia uses against these countries. Although long-term cuts are a low possibility, they can be expected of Russia. Since 1991, Russia has been using energy as a political and economic tool. The number of events such as pressures on such countries as Lithuania, Latvia, Estonia, Belarus, Ukraine, Moldova and Georgia, in a way that covers most of Europe, accidents, energy cuts, selling out companies to others, coercive pressure policies, blackmails or threats exceeds 50. Almost half of them occurred during Putin's government (during first five years of his rule) (Larsson, 2006: 3, 4). Some European countries have become dependent on Russia in the energy area through the agreements that they have concluded with Moscow. The level of European dependence to Russian gas is seen in Image 2. However, this situation includes many risks for Europeans. Finon and Locatellisummarize this situation as follows;

manipulating the European market, risk of cancellation of the contract unilaterally, inadequate investments that can be withstand for long periods against the prices, circulating European energy market after constructing north stream and south stream, agreement with Turkey to discourage the construction of direct supply lines for Caspian gas to the European market, moves to reach agreement with major distributors, in particular Sonatrach, or even the takeover of distributors with a dominant position in specific national markets to partition markets (Finon and Locatelli, 2007: 2).

Accordingly, in case of any crises between Europeans and Russia, Moscow gains the opportunity to put political and economic pressures on Europe ${ }^{4}$. The disagreements about the price of the natural gas that Russia

\footnotetext{
${ }^{4}$ In this part of the study, a reference made to (Sönmez et al., 2015: 802)
} 
exports to Ukraine affect not only these two countries, but also the entire Europe. By increasing usuriously natural gas prices before the critical elections in Ukraine, Moscow aimed the electoral victory of the proponents of Russia. Before 2006 Parliamentary Elections after Orange Revolution as well as the Presidential Elections in 2010, Russia resorted to this method. Russia wanted to raise the price of gas per 1000 cubic meter \$50 to \$230 in 2006 and from \$250 to \$418 in 2009. However, upon Kiev's rejection of both increases, Russia cut the gas transportation to Ukraine. Therefore, Russia punished Orange Revolution and intimidated Ukrainian people. This policy yielded some results; pro-Russian Yanukovych came through 2010 elections (Sar1, 2015: 83-84). In 2013, protests against the pro-Russian government that did not sign the EU Customs Union Agreement led to another crisis between Russia and Ukraine. The Kremlin started to put serious pressures on Ukraine to pay its debts. Annexing Crimea as a result of the problems that occurred in the eastern region of Ukraine in this period, Russia at first decreased the gas transported to Kiev until June 2014 and then completely cut it. However, Kremlin took a step back and continued delivering gas. Yet, Russia limited the discount in the energy prices, which it uses as a foreign policy tool. The Kremlin left amargin in legal context for Europe and the international area (Stulberg, 2015: 112). Additionally, Russia brought forward a discount in the prices of the gas it sold to Ukraine between 2006 and 2010. The fundamental reason for such a discount was its existing military base in Crimea (Orttung and Overland, 2010: 84). In fact, in 2010, when pro-Russian Yanukovych was ruling, Russia made a-30\%-discount in the gas price (Orttungand Overland, 2010:75). In exchange for this discount, Ukraine concluded an agreement, which allowed Russian Black Sea Fleet in Sevastopol to stay there until 2042, with Russia. In 2012, when Yanukovych requested Russia to make a discount in the gas prices, Russian Prime Minister Medvedev expressed that Kiev also should be a member of Eurasian Economic Union established under Russia's leadership (Sar1, 2015: 85).

Russia also has pressured Moldova within the context of energy policies. Upon the fact that the Kremlin doubled the gas prices, Moldova rejected this price increase. As a response to that rejection, state-subsidized Gazprom cut the gas flow to Moldova on January 1, 2006. The flow of gas was provided again after January 17 and the price of gas per 1000 cubic meter, which was previously $\$ 60$, was raised to $\$ 100$. Furthermore, Moldova had to sell Transnistria, which had $13 \%$ of the stocks at Moldova Gas Company controlling natural gas pipelines and other infrastructure of the country, to Russia (Woehrel, 2009: 11). As a result of the problems that occurred between Russia and Georgia in 2006, Russia cut the flow of gas and 
electricity to Georgia. Throughout this year, Azerbaijan met the energy need of Georgia (www.trend.az).

Belarus, one of the former-Soviet Union countries, is also dependent on Russia in terms of energy. On January 1, 2007, upon Belarus's reservation about the high prices, Russia declared that it would stop the gas flow. Then, an agreement was concluded between Moscow and Minsk and Belarus committed to buy the gas by paying the double price (Woehrel, 2009: 13). Against the propaganda for supporting fascism, conducted in Lithuania in 2012, Russian government decided toplace an economic embargo on this country. Stating that European Union remains silent on the events supporting fascism, Russia blackmailed Lithuania to close both the gas and the oil valves (www.5-tv.ru/news).

Moreover, it is possible to say that countless numbers of states follow carrot-stick policy in order to force another country to do things in the way they. Bulgaria, particular Baltic States and Armenia among these countries have been exposed to Russia's carrot or stick policies. Therefore, the energy resources that Russia uses as a source of political pressure, are its insurance.

\section{The Policy of Changing the Energy Routes}

Russia can change its energy routes with the countries it has problems. In the beginning of the 2000s, approximately $95 \%$ of the gas that was transferred from Russia to Europe used to be transported over Ukraine. This meant that Russia was dependent on Ukraine in terms of energy transfer. In some cases, Ukrainian government illegally hauled and used the gas coming through the pipelines. It was even reported that Ukraine sold this gas to the other countries. One of the reasons that Russia kept interfering in the elections in Ukraine was this dependency relationship (Torbakov, 2001: 297-304). Later on, Russia tried to increase the number of its transportation routes and started to get rid of its dependency on the transit countries. New countries of transit have supported Russia's policy in this respect. For example, Yana Toom, an Estonian member of the European Parliament, states that Ukraine's gas transportation systems are 40 years old. Implying that Ukraine's lines are old and technologically inadequate for a transit route from Russia to Europe, Toom emphasized that the North Stream Project 2 should be used (http://rg.ru).However, according to another news agency, Russia may have to use Ukraine's pipelines again in order to be able to send gas to Europe. The reason behind this is that it may be more expensive to construct new gas transportation pipelines. Notwithstanding, the agreements point to the fact that the gas transportation system passing through Ukraine will have been completely removed by 2022.Some experts state that even if the system in question is removed, it will not be appropriate to go for a choice that does not contain Ukraine in the future (http://www.gazeta.ru). 
Another policy that Moscow adopted to create alternative routes was developed after the plane crisis arisen between Russia and Turkey. According to RiaNovosti, a Russian newspaper, Russia decided to stop the Turkish Stream Project in the context of the new energy policy shaped through the crisis arisen between Turkey and Russia on November 24, 2015. However, Russia continues to sell gas to Turkey due to the agreements concluded by the two countries (http://ria.ru).

It is important to point out that Russia is not the only country that has gone for a change in the routes. As an extension to the sanctions imposed on Russia by the Western countries upon the annexation of Crimea, the EU pressured Bulgaria to deter from being one of the transit countries in the South Stream Project (www.euractiv.com). Consequently, the part in Bulgaria of the project was stopped in 2014 (Andreev, 2014: www.dw.com). However, after the crisis between Turkey and Russia occurred on November 24, 2015 when Turkish warplanes shot down a Russian military aircraft, The Bulgarian authorities announced that the project would start again (www.focus-fen.net).

Russia determines not only the routes through which its own energy resources will pass. It has also followed a policy to ensure that the Central Asian and Caucasian energy resources will be transported to the West through the Russian territories. In the 1990s, when transportation of the energy resources of countries such as Azerbaijan, Kazakhstan and Turkmenistan to international emerged, Russia used the status of the Caspian Sea $^{5}$ as an excuse and tried to prevent signing oil or natural gas agreements between the relevant countries and Western energy companies. With this purpose in mind, Russia contributed to the internal disorder in those countries by even supporting coups. When Russia failed in these attempts, it pressured these countries to agree to transport energy to the West through the Russian territories. In the 1990s, Azerbaijan and Georgia were particularly exposed to the Russian pressure due to the reasons mentioned above. ${ }^{6}$

\footnotetext{
${ }^{5}$ As the largest closed water mass in the World, the Caspian has led to a discussion regarding 'whether it is a sea or a lake' and created a sharing problem among the littoral countries.

${ }^{6}$ Soon after AbulfazElchibey concluded certain energy agreements with some of the Western countries, a coup was staged. Heydar Aliyev, who came to power after Elchibey, concluded an agreement with some of the Western powers on September 20, 1994. This agreement was called the 'Contract of the Century'. Two weeks after the agreement, another coup was staged now against Aliyev, but it failed (İssyar, 2004: 524). The Aliyev government gave $10 \%$ share to the company of Lukoil through the agreement and tried to appease Moscow. However, Moscow started to pressure Azerbaijan from then on to have the pipelines on the Russian territories (Purtaş, 2005: 232). What Moscow preferred was to transport all the Azeri oil to the Black Sea through the line of Baku-Novorossiysk. It also pressured Eduard Schewardnadze not to let the oil be transported through the alternative line crossing over Georgia. However, when this pressure policy yielded no result, Schewardnadze was
} 
Although,its repressive policies did not yield results in Caucasus, but Russia succeeded to transport oil of Kazakhstan and gas of Turkmenistan to the global market through its territories. The Kazakh government planned to transport the oil drilled from the Tengiz region of the Kazakhstan to the Mediterranean Sea via the BTC line. With this purpose in mind, a joint declaration was signed in October 1998 by the presidents of Turkey, Georgia, Azerbaijan, Kazakhstan, Uzbekistan and the energy secretary of the USA (observer). Russia opposed this project from the outset. As a consequence, it prevented the project of Tengiz-Baku-Ceyhan from being put into practice. The Kazak oil drilled from the Caspian Sea had been transported to the Black Sea trough the Georgian Supsa harbor dating from November 1997. However, Russia opposed this situation as well, and ensured that the oil started to be pumped to the Russian Novorossisk harbor at the Black Sea (Baycaunova, 2000: 268-270). Moreover, Russia and Kazakhstan agreed on the Caspian Pipeline Consortium (CPC) which would transport the Kazak oil to the Black Sea through the Tengiz-Atırau-AstrahanNovorossisk line and started its construction in 1998 (Bayacaunova, 2000: 263).

In the 1990s, Turkmenistan embarked on a quest for alternative routes to have its natural gas transported to international markets. The Turkmen government negotiated with Washington, Ankara and Tehran with this purpose in mind. The Trans Caspian project supported by the USA came to the fore in this period. However, it became impossible to find an alternative route to the Russian one due to Russia's pressures, the breakdown of the relationship between Azerbaijan and Turkmenistan and the USA policy to exclude Iran from the routes of energy pipelines (Soltan, 2001: 195-196).

Russia wants to keep Eurasia under control for geopolitical reasons as well as for its energy security. Eurasia is the crucial point in all energy policies in the world. Being the junction point where energy resources and global relations meet, Eurasia is the center of global decisions. Delivering regional resources into international corridors is one of the leading issues regarding the Central Asia. And the Western World wishes to have a corridor construction that will be independent from Russia (Naumkin, 1999: 1-17).

The USA and the EU, too, have started to support alternative routes against the Russian policy to be a monopoly in the market of transit countries. As opposed to the Russian North-South corridor, the USA and the EU wish to consolidate the East-West corridor which excludes Russia and

assassinated (Pamir, 1999: 36-37). Russia’s pressure policies intended for Azerbaijan and Georgia remained inconclusive. The line of Baku-Tbilisi-Ceyhan (BTC) started to be constructed in September 2002 and the production began in 2005 (www.btc.com.tr). 
Iran. With this purpose in mind, a series of negotiations were carried out in the hope to transport the Kazak and Turkmen oil resources through the BTC line (Telli, 2015: 138). Consequently, Kazakhstan at 2008 and Turkmenistan at 2010 started to transport some part of their oil resources via the BTC line. In this way, the CentralAsian countries managed to by-pass Russia for the first time and transported some part of their energy resources to the Western market by-passing Russia(Telli, 2015: 224). Moreover, Kazakhstan and Turkmenistan have been tending towards Chine in order to alleviate their dependency on the Russian pipelines (Telli, 2015: 169).

In recent years two projects ${ }^{7}$ have come to the fore, one being the project of Nabucco Pipeline which will transport the Azeri and Turkmen gas to the European market and the other being the project of Trans-Anatolia Natural Gas Pipeline (TANAP) which will transport the Azeri gas to the European market. However, Russia has adopted various tactics in the hope to interfere with these pipeline projects. First, Russia came up with the South Stream Project as an alternative to the TANAP. Then, it proposed "to purchase all the Azeri gas for its market value'. Although this proposal was rejected by Azerbaijan, Russia managed to persuade it to conclude another agreement. According to this agreement in 2009, Russia started to import gas from Azerbaijan for the North Caucasian republics. "Russia also accepted to pay for the Azeri gas the same highest price as the one that it pays to import gas from the Caspian and the Central Asia. Wishing to continue its control over the natural gas reserves in the Middle Asia and the Caspian and be an element of pressure in terms of the transfer corridor, Russia approached Azerbaijan with quite reasonable conditions and thus prevented it from go towards the West completely"” (Telli, 2015: 367-369). Moreover, Russia pressured the countries that had planned to give gas to the Nabucco pipeline. In order not to let the Nabuccoproject to stand, Russia made a last move in 2013 and applied a serious price reduction to the natural gas that it sold to Europe, thus discredited the Shah Sea Consortium (Telli, 2015: 373).

\footnotetext{
${ }^{7}$ Natural gas reserves were found in the Shah Sea region of Azerbaijan at the end of the 1990s. Then, with its connections with Turkey, Greece and Italy, the Baku-Tbilis-Erzurum natural gas pipeline were constructed in parallel with the BTC line (Telli, 2015: 367). Thanks to this project, The Azari natural gas will by-pass Russia by crossing over Turkey and reach Europe, so that the EU will alleviate its energy dependency on Russia. The BTE project is the first serious attempt to ensure the transportation of the Caspian gas to the EU through a non-Russian route. However, only the lines that will cross over Azerbaijan, Georgia and Turkey have yet been completed. Consequently, the Nabuccodaha and TransAnatolia Natural Gas Pipelines (TANAP) came to the fore in order to enable the BTE line reach Europe. As indicated before, the project of Trans-Caspian Pipeline designed in the 1990s to transport the Turkmen gas to Europe through Turkey remained on paper. However, the project of Nabucco aims to transport the Turkmen gas to Europe, as well.
} 
Although Russia could not obstruct the TANAP, it stopped the Nabucco project and prevented the transmission of the Turkmen gas to the West.

As a result it should be mentioned that, Russia has been implementing the following strategies to shape its policy regarding the energy routes:

1. Preventing its energy resources from getting into the global market through alternative pipelines over which it does not have any control and thus putting these alternative pipelines in a disadvantageous position by constructing new pipelines to transport energy for more affordable prices,

2. Constructing new pipelines and thus transport energy to the importer countries in Europe without any need for transit countries,

3. Preventing non-Russian alternative projects from being put into practice by purchasing the distribution systems in Europe through Gazprom (Telli, 2015: 356-357).

\section{Conclusion}

The ideological discourse that Moscow used in the Cold War era constituted one of the most important dimensions of the Russian foreign policy. In these years, the ideological expansionism was one of factors that enabled the Soviet Union to enlarge its sphere of influence on a global level. In the post Cold war period, Russia's political power andability to maneuver have been increasing through the 'energy factor'. Currently Russia is exporting energy instead of ideology. Moscow was able to control the Soviet Republics and the East Bloc countries by means of Red Army in the Cold War period. Similarly, Russia now tries to dominate the former-Soviet Republics through its economic power and energy policies. In brief, the contemporary Russian energy policies have placed socialism and Red Army, two important components reminding us of the Cold War period and the Soviet policies.

As indicated before, the Russian economy caught a rapid growth trend due to the reasons such as the rise of energy prices in international markets in the new millennium. Growing economically, Russia has done its best to consolidate its power in the former Soviet geography. Putin has increased Moscow's influence in the region by first concluding agreements with the Central Asian countries regarding the domain of energy. After the blockage occurred in the Colour Revolution in 2005 in Uzbekistan, the USA lost some part of its influence in the region, as a result of which Russia got rid of its most important rival in the region. Countries such as Kazakhstan, Kirghizstan, Tajikistan, Armenia and Belarus participated in the regional organizations established with the leadership of Russia,and thus being 'warded' by her. Choosing to follow a foreign policy oriented to the West, 
Georgia and Ukraine have been exposed to Russia's power policy. Consequently, while some countries have become dependent on Russia because of the economic and political opportunities that it seems to offer, the countries such as Azerbaijan, Georgia and Ukraine have gradually been moving away from it.

Russia has succeeded to make Europe dependent on it in terms of natural gas. Moscow's energy policies have yielded some results which have consolidated Russia's power in the region. However, it cannot be denied that these policies also include many risks. For example, The EU countries that are dependent on Russia get confused by its practices such as cutting off Ukraine's gas or increasing the gas price that it used to pay. Therefore, they try to import natural gas from other countries in order to come over this dependency problem. This is the fundamental reason behind the projects which aim to transport the Azeri and Turkmen gas to Europe. Moreover, after the removal of the sanctions imposed on Iran, this country can be an alternative to Russia for Europe since it can both supply natural gas and become a transit country to transport the Central Asian energy resources to Europe.

On the other hand, it is impossible for Russia to do the same thing to all of its clients as the one it did to Ukraine. It would let Russia's trustworthiness be interrogated and deprive it of the income it generated from the energy industry. This is also the reason behind the fact that although Russia imposed certain economic sanctions on Turkey after the planecrisis, it could not use its natural gas card.

Finally, it is necessary to point out that Russia's great energy resources are both an advantage which constitutes the great power that it has and a soft belly waiting to be discovered. Russia's economic power and foreign policy have become dependent on global energy prices. Although energy prices have been high in the new millennium so far, they show the signs of decreasing nowadays. If this decreasing trend continues in this manner, the Russian economy may get weaker as in the 1980s and 1990s and result with being passivated inits foreign policy again.

\section{References:}

Ageev, A. iLoginov, E. (2014), Snijenie Mirovih Tsenna Neft: ViderjitliRossiya? Vektor Peremen.

Andreev, A. (2014), “Strife over South Stream”, http://www.dw.com/en/strife-over-south-stream/a-17703641, (accessed, 28 October 2015).

Arı, T. (2011), Uluslararası İlişkilerve Dış Politika, 9. Press, MKM Publishing: Bursa. 
Baycaunova, S. (2000), “Kazakistan Petrol ve Gazının Türkve Rus Diş Politikalarındaki Yeri ve Önemi”, Avrasya Dosyası, Vol. 6 (2), pp. 252-276. Baytekin, S. (2010), 2006 Sonras Rusya'nın Dış Politikasında Enerjinin Yeri, Doctoral Thesis, Graduate School of Social Science, Hacettepe University, Ankara

Bilgin, M. (2005), Avrasya Enerji Savaşlarl, IQ Culture and Publishing: Istanbul

Chernitsina, S. (2015), Rol Energeticheskoy Diplomatii v Formirovanii Vneşney Politiki Rossiina Sovremennom Etape (2000-2014), Dissertatsiya, Moskovskiy Gosudarstvenniy Institut.

Chyong, C. K., Noel, P. \&Reiner, D.M. (2010), The Economics of the Nord Stream Pipeline System, Cambridge Working Paper in Economics.

Darmstadter, J. (2013), "Recalling the Oil Shock of 40 Years Ago", http://www.rff.org/files/sharepoint/WorkImages/Download/RFF-IB-1306.pdf, (accessed, 28 October 2015).

Erbil, Y. (2010), Rusya-UkraynaDoğalGazKriziveEnerjiGüvenliği, Graduate School of Social Science, Doctoral Thesis, Kadir Has University: İstanbul.

Finon, D. and Locatelli, C. (2007), Russian and European gas interdependence, Can market forces balance out geopolitics?, https://halshs.archives-ouvertes.fr/halshs-00129618v2/file/Cahier41bis.pdf, (accessed, 28 October 2015).

Houtari, J. (2011), Energy Policy and (energy security) as a part of Russian Foreign Policy, Nordia Geographical Publications, Vol: 40, No: 4, pp. 121132

Goldthau, A. (2008), Resurgent Russia? Rethinking Energy Inc. Policy Review, No: 147. http://www.euractiv.com/sections/energy/bulgariacommission-lost-translation-over-south-stream-301751, (accessed, 28 October 2015).

Henderson, J. (2015), Key Determinants for the Future of Russian Oil Production and Exports. University of Oxford Institute for Energy Studies, Oxford.

https://en.wikipedia.org/wiki/United_Nations_General_Assembly_Resolutio n_3379 -(c) (accessed, 28 October 2015).

https://en.wikipedia.org/wiki/Energy_in_Russia-(a), (accessed, 28 October 2015).

http: en.wikipedia.org/wiki/List_of_countries_by_natural_gas_production(b) (accessed, 28 November 2015).

http://en.transneft.ru/about/corporate-information/?re=en, (accessed, 28 November 2015).

http://www.eia.gov/todayinenergy/detail.cfm?id=22392, (28 November 2015).

http://www.btc.com.tr/proje.html, (accessed, 28 November 2015). 
https://www.cia.gov/library/publications/the-worldfactbook/rankorder/2244rank.html (accessed, 28 November 2015). http://www.focus-fen.net/news/2016/01/12/394776/bulgaria-in-the-foreignmedia-january-11- roundup.html (accessed, 13 December 2015). http://www.lukoil.ru/static_6_5id_29_.html, (accessed, 28 November 2015). http://www.trend.az/azerbaijan/politics/779110.html, (accessed, 28 November 2015). http://www.5-tv.ru/news/52477(accessed, 26 December 2015). http://rg.ru/2015/12/18/tranzit-site-anons.html (accessed, 18 December 2015).

http://ria.ru/economy/20151201/1333951983.html / (accessed, 28 December 2015).

http://www.gazeta.ru/business/2015/12/03/7932443.shtml / (accessed, 26 December 2015).

http://www.gazprom.ru/about/production/projects/pipelines/power-ofsiberia2/(c), (accessed, 26 December 2015).

http://www.gazprom.ru/about/production/projects/pipelines/ (b), (accessed, 26 December 2015).

http://www.btc.com.tr/proje.html, (accessed, 28 December 2015). https://www.eia.gov/beta/international/analysis.cfm?iso=RUS, (accessed, 19 February 2016). https://www.google.com.tr/search?q=russia+energy+corridors\&rlz=1C2AV NG_enTR637TR 637\&biw=, (accessed, 18 February 2016). http://www.zerohedge.com/news/2014-09-10/russian-retaliation-beginsgazprom-limiting-eu- gas-cuts-poland-supplies-20-past-two-, (accessed, 18 February 2016). http://www.iefe.unibocconi.it/wps/wcm/connect/d4fd383f-cf3f-4625-ad05fca4e184d44d/Slides+Chyong+February+2015.pdf?MOD=AJPERES (accessed, 17 March 2016).

ICONICS, (2010), Transneft Russian Pipeline, http://www.iconics.com/IconicsWebsite/media/Documents/OilDownloads/ss -ogp- transneft.pdf. (accessed, 28 October 2015).

İşyar, G. (2004), Bölgeselve Global Güvenlik Çıkarları Bağlamında SovyetRus Dış Politikalarıve Karabağ Sorunu, Alfa Publishing: Istanbul.

Kanet, R. E. (2008), The Return of Imperial Russia: Russia and Its Neighbours, ACDIS Occasional Paper, University of Illinois at Urbana.

Kavkaza, V. (2014), "Unipolar world is coming to an end, Putin says” (May 23, 2014) http://www.prisonplanet.com/unipolar-world-is-coming-to-an-endputin- says.html (accessed, 28 December 2015).

Larsson, R. L. (2006), Russia's Energy Policy: Security Dimensions and Russia's Reliability as an Energy Supplier, Swedish Defense Research Agency 
Mitrova, T. (2008), Gazprom's Prospective on International Markets", Russian Analytical Digest, Moscow, Vol: 41, No: 08, pp.2-17.

Naumkin, V. V. (1999), "The emerging geopolitics balance in Central Asia: a Russia view",

Russia and Asia: the emerging security agenda. pp. 83-99 http://books.sipri.org/files/books/SIPRI99Chu/SIPRI99Chu05.pdf, (accessed, 05 January 2016).

Onay, Y. (2007), Batı'ya Direnen Devlet Rusya, Yeniyüzyıl Publishing: Istanbul

Orttung, R. W. and Overland, I. (2011), A limited toolbox: Explaining the constraints on Russia's foreign energy policy. Journal of Eurasian Studies, Vol: 2, No: 1, pp. 74-85.

Pamir, N. (1999), Orta Asyave Kafkasya'da Bitmeyen Oyun: Bakü-Ceyhan Boru Hattı, ASAM, Ankara.

Purtaş, F. (2005), Rusya Federasyonu Ekseninde Bağımsız Devletler Topluluğu, Platin Publishing: Ankara.

Rasporyajenie 1715R (2009), Energeticheskaya Strategiya Rossiina period do 2030. http://www.consultant.ru/document/cons_doc_LAW_94054/, (accessed, 28 November 2015).

Rasporyajenie 1234R (2003), Energeticheskaya Strategiya Rossiina period do

2020,http://www.cpnt.ru/userfiles/_files_normativ_energosafe_energostrateg y.pdf, (accessed, 27December 2015).

Rosneft (2015), Rosneft at a Glance, http://www.rosneft.com/about/, (accessed, 28 November 2015).

Sarı, G. (2015), AB YolundaUkrayna: AvrupaKomşulukPolitikası ABUkraynaIllişkileri, Master Thesis, Atılım University, Ankara.

Smith, K. (2008), Russian Energy Policy and its Challenge to Western Policy Makers, Center for Strategic and International Studies, Washington. D.C.

Socor, V. (2008), "Gazprom, the Prospects of a Gas Cartel, and Europe's Energy Security”, Svante E. Cornell and Niklas Nilsson (ed.), Europe's Energy Security: Gazprom's Dominance and Caspian Supply Alternatives ,Caucasus Institute \& Silk Road Studies Programme, pp. 71-83.

Soltan, E. (2001), Türkmenistanve Rusya: Gaz Üzerinde Kurulan İlişkiler? Avrasya Dosyası, Türkmenistan Özel, 7(2), pp. 184-205.

Sönmez, A. S. (2010), “Moskova'nın Kutuplaşma Çabaları: Putin Dönemi Rus Dış Politikası",Avrasy Etüdleri, Vol: 16, No: 37, pp. 37-76.

Sönmez, A. S. (2015), "Kırım Sorunu Bağlamında Rusya Ukrayna İlişkilerinin Analizi” International Journal of Social Sciences and Education Research, Vol: 1, No: 3, pp.790-808.

Stern, J. (2005), Natural Gas in Europe-TheImportance of Russia. Oxford Institute for Energy Studies, Oxford, Doctoral Thesis. 
Stulberg, A. N. (2015), Out of Gas?: Russia, Ukraine, Europe, and the Changing Geopolitics of Natural Gas. Problems of Post-Communism, Vol: 62, pp. 112-130.

Sudo, M. M., iKazankova, E. R. (1998), Energeticheskie Resursı, Nefti Prirodnoygaz, Vek Uhodyaşiy, Rossiya v Okrujayuşçem Mire. http://www.rus-stat.ru/stat/1931998_6.pdf (accessed, 18 October 2015).

Telli, A. (2015),Hazar Havzası Enerji Diplomasisinde Rekabetve Isşbirliği, Kocaeli University,

Graduate School of Social Science, Doctoral Thesis, Kocaeli.

The October 1973 energy crisis, https://networks.h-net.org/ system/ files/ contributed- files/henergy-f-venn-1973-oil-crisis.pdf (accessed, 18 July 2015)

The Soviet Gas Pipeline in Perspective, (1982), Special National Intelligence Estimate, http://www.foia.cia.gov/sites/default/files/document_conversions/ 17/19820921.pdf, (accessed, 18 July 2015).

Torbakov, I. (2001), Rusya’dan Ayrıya da Rusya’nın Bir Parçası: UkraynaRusya İlişkilerinin Kederli Bir Destanı, Avrasya Dosyası, Vol: 6, No: $\quad 4$, pp. 297-314.

US Energy Information Administration, (2015), International energy data and analysis:

https://www.eia.gov/beta/international/analysis_includes/countries_ long/Russia/russia. Pdf (accessed, 18 July 2015).

Ülger, İ. K. (2002), AvrupaBirliğindeSiyasalBütünleşmeOrtakDışveGüvenlik PolitikasınınOluşumu, Gündoğan Publishing: Ankara.

WEO, (2011), Annualy Report, International Energy Agency, https://www.iea.org/publications/freepublications/publication/WEO2011_W EB.pdf, (accessed, 28 November 2015).

Workma, D. (2016), “Crude Oil Exports by Country” (January 16, 2016), http://www.worldstopexports.com/worlds-top-oil-exports-country/3188, (accessed,_18 January 2016).

Woehrel, S. (2009), Russian Energy Policy Toward Neighboring Countries, CRS Report for Congress, https://www.fas.org/sgp/crs/row/RL34261.pdf (accessed, 28 November 2015). 
Table 1: Estimated Proved Natural Gas Reserves, as of January 1, 2015 trillion cubic feet

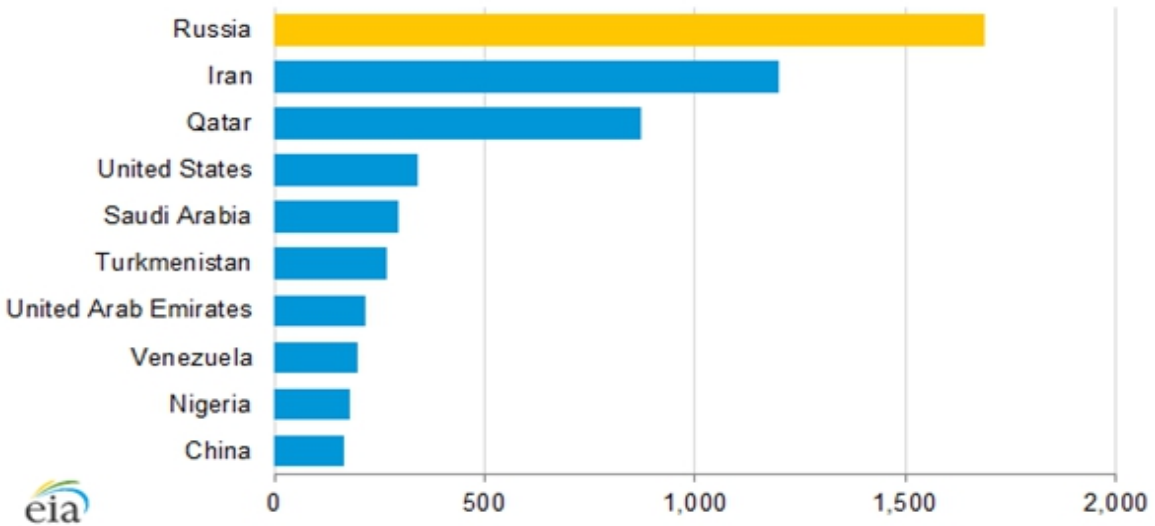

Reference:www.eia.gov/beta/international/analysis_includes/countries_long/Russia/russia.p df, p.11

Table 2: Natural Gas Production

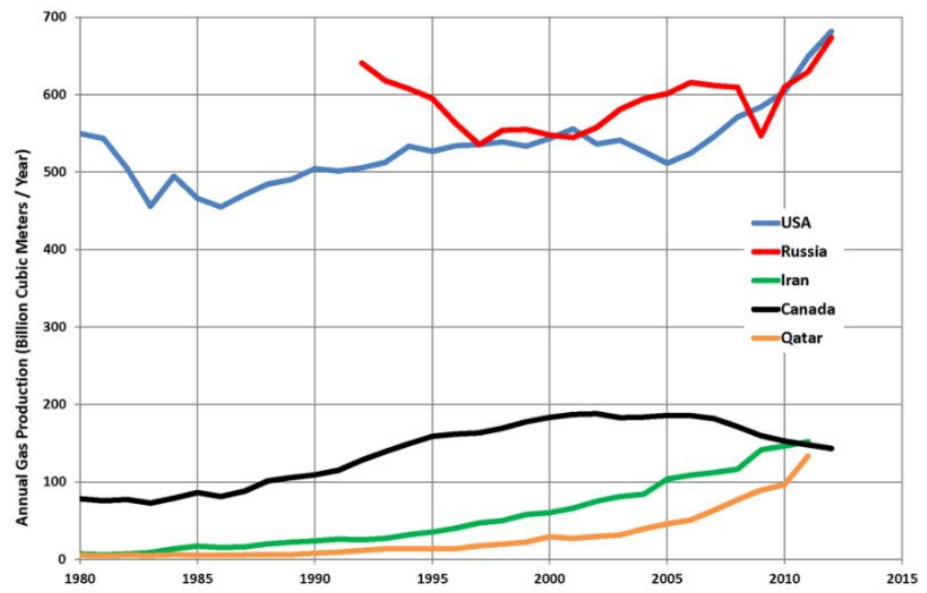

Reference: en.wikipedia.org/wiki/List_of_countries_by_natural_gas_production

Table 3: Russia Crude Oil (including condensate) production and exports million barrels per day

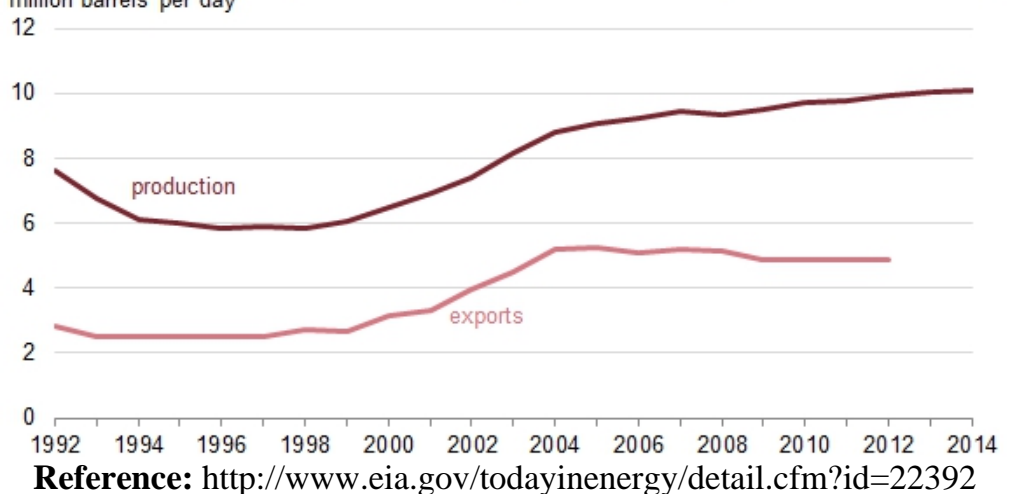


Table 4: Russia’s Major Crude Oil Pipelines

\begin{tabular}{|c|c|c|c|c|c|c|}
\hline Facility & Status & Capacity (million b/d) & Total length (miles) & Supply regions & Destination & Details \\
\hline \multicolumn{7}{|l|}{ Western pipelines } \\
\hline Druzhba & operating & 2 & 2,500 & $\begin{array}{l}\text { West Siberia and } \\
\text { Urals-Volga } \\
\text { regions }\end{array}$ & Europe & completed in 1964 \\
\hline $\begin{array}{l}\text { Baltic Pipeline } \\
\text { System } 1\end{array}$ & operating & 1.3 & 730 & $\begin{array}{l}\text { connects to } \\
\text { Druzhba }\end{array}$ & $\begin{array}{l}\text { Primorsk Port on } \\
\text { the Gulf of } \\
\text { Finland }\end{array}$ & completed in 2001 \\
\hline $\begin{array}{l}\text { Baltic Pipeline } \\
\text { System } 2\end{array}$ & operating & 0.6 & 620 & $\begin{array}{l}\text { connects to } \\
\text { Druzhba }\end{array}$ & $\begin{array}{l}\text { Ust-Luga Port on } \\
\text { the Gulf of } \\
\text { Finland }\end{array}$ & completed in 2012 \\
\hline $\begin{array}{l}\text { North-West } \\
\text { Pipeline System }\end{array}$ & inactive & 0.3 & 50 & $\begin{array}{l}\text { connects to } \\
\text { Druzhba }\end{array}$ & $\begin{array}{l}\text { Butinge, } \\
\text { Lithuania and } \\
\text { Ventspils, Latvia } \\
\text { on the Baltic } \\
\text { Sea }\end{array}$ & inactive since 2006 \\
\hline $\begin{array}{l}\text { Caspian Pipeline } \\
\text { Consortium } \\
\text { (CPC) }\end{array}$ & operating & 0.7 & 940 & $\begin{array}{l}\text { Tengiz field, } \\
\text { Kazakhstan }\end{array}$ & $\begin{array}{l}\text { Novorossiysk, } \\
\text { Russia on the } \\
\text { Black Sea }\end{array}$ & $\begin{array}{l}\text { Planned expansion to } \\
1.3 \text { million b/d by } \\
2016\end{array}$ \\
\hline $\begin{array}{l}\text { Baku- } \\
\text { Novorossiysk } \\
\text { Pipeline }\end{array}$ & operating & 0.1 & 830 & $\begin{array}{l}\text { Caspian and } \\
\text { central Asia, via } \\
\text { Sangachal Port, } \\
\text { Azerbaijan on } \\
\text { the Casnian Sea }\end{array}$ & $\begin{array}{l}\text { Novorossiysk, } \\
\text { Russia on the } \\
\text { Black Sea }\end{array}$ & completed in 1996 \\
\hline \multicolumn{7}{|l|}{ Eastern pipelines } \\
\hline TransSakhalin & operating & 0.2 & 500 & $\begin{array}{l}\text { Sakhalin fields } \\
\text { (offshore } \\
\text { northern } \\
\text { Sakhalin) }\end{array}$ & $\begin{array}{l}\text { Pacific seaport } \\
\text { of Prigorodnoye } \\
\text { (Southern } \\
\text { Sakhalin Island) }\end{array}$ & completed in 2008 \\
\hline $\begin{array}{l}\text { Eastern Siberia- } \\
\text { Pacific Ocean } \\
\text { (ESPO) Pipeline }\end{array}$ & operating & $\begin{array}{c}\text { ESPO- } 1-1.2 \\
\text { currently, } \\
1.6 \text { by } 2020 \\
\text { ESPO- } 2-0.5 \\
\text { currently, } \\
1.0 \text { by } 2020 \\
\text { China spur }-0.3 \\
\text { currently, } \\
0.6 \text { by } 2018\end{array}$ & $\begin{array}{c}\text { ESPO-1 }-1,700 \\
\text { ESPO-2- } 1,300 \\
\text { Daqing spur }-660\end{array}$ & $\begin{array}{l}\text { East Siberian } \\
\text { fields and, via } \\
\text { connecting } \\
\text { pipelines, West } \\
\text { Siberian fields } \\
\text { and Yamal- } \\
\text { Nenets region }\end{array}$ & $\begin{array}{l}\text { Pacific seaport } \\
\text { of Kozmino with } \\
\text { a spur to } \\
\text { Daqing, China }\end{array}$ & $\begin{array}{l}\text { ESPO-1 (Taishet- } \\
\text { Skovorodino) } \\
\text { completed in } 2009 \\
\text { ESPO-2 } \\
\text { (Skovorodino- } \\
\text { Kozmino) completed } \\
\text { in } 2012 \text { Skovorodino- } \\
\text { Daqing, China spur } \\
\text { completed in } 2010\end{array}$ \\
\hline $\begin{array}{l}\text { Purpe-Samotlor } \\
\text { Pipeline }\end{array}$ & operating & 0.5 & 270 & $\begin{array}{l}\text { Yamal-Nenets } \\
\text { and Ob Basins }\end{array}$ & $\begin{array}{l}\text { connects to } \\
\text { ESPO Pipeline }\end{array}$ & completed in 2011 \\
\hline $\begin{array}{l}\text { Zapolyarye- } \\
\text { Purpe Pipeline }\end{array}$ & construction & 0.6 (expandable to 0.9 ) & 300 & $\begin{array}{l}\text { Zapolyarye and } \\
\text { Yamal-Nenets } \\
\text { region }\end{array}$ & $\begin{array}{l}\text { connects to } \\
\text { Purpe-Samotlor } \\
\text { and ESPO } \\
\text { pipelines }\end{array}$ & $\begin{array}{l}\text { Planned for } 2016 \text { may } \\
\text { be delayed 2-3 years } \\
\text { or may carry minimal } \\
\text { volumes }(30,000 \mathrm{~b} / \mathrm{d}) \\
\text { as field completions } \\
\text { have been delayed }\end{array}$ \\
\hline $\begin{array}{l}\text { Kuyumba- } \\
\text { Taishet }\end{array}$ & construction & 0.16 & 430 & $\begin{array}{l}\text { Kuyumba field } \\
\text { (start- up } \\
\text { delayed until } \\
\text { 2018) }\end{array}$ & $\begin{array}{l}\text { connects to } \\
\text { ESPO Pipeline }\end{array}$ & $\begin{array}{l}\text { Planned for } 2016 \text {, } \\
\text { may be delayed or } \\
\text { may carry minimal } \\
\text { volumes as field } \\
\text { completions have } \\
\text { been delayed }\end{array}$ \\
\hline
\end{tabular}

Reference: https://www.eia.gov/beta/international/analysis.cfm?iso=RUS 
Table 5:Russia’s Major Natural Gas Pipelines

\begin{tabular}{|c|c|c|c|c|c|c|}
\hline Facility & Status & $\begin{array}{l}\text { Capacity } \\
\text { (trillion } \\
\text { cubic } \\
\text { feet per } \\
\text { year) }\end{array}$ & $\begin{array}{l}\text { Total } \\
\text { length } \\
\text { (miles) }\end{array}$ & Supply regions & Markets & Details \\
\hline \multicolumn{7}{|c|}{ Western pipelines } \\
\hline Yamal-Europe & operating & 1.2 & $\begin{array}{r}\text { more } \\
\text { than } \\
1,000\end{array}$ & $\begin{array}{l}\text { West Siberian fields } \\
\text { including Urengoy } \\
\text { area }\end{array}$ & $\begin{array}{l}\text { Poland, Germany, and } \\
\text { northern Europe via Belarus }\end{array}$ & \\
\hline Blue stream & operating & 0.6 & 750 & $\begin{array}{l}\text { West Siberian fields } \\
\text { including Urengoy } \\
\text { area }\end{array}$ & Turkey via the Black Sea & Started operations in 2003 \\
\hline Nord stream & operating & 1.9 & 760 & $\begin{array}{l}\text { West Siberian fields } \\
\text { including Urengoy } \\
\text { area }\end{array}$ & $\begin{array}{l}\text { Germany and northern } \\
\text { Europe via the Baltic Sea }\end{array}$ & Started operations in 2011 \\
\hline $\begin{array}{l}\text { Urengoy- } \\
\text { Ukhta, } \\
\text { Bovanenkovo- } \\
\text { Ukhta, and } \\
\text { Ukhta-Torzhok }\end{array}$ & $\begin{array}{l}\text { operating } \\
\text { and under } \\
\text { construction }\end{array}$ & up to 6.0 & $\begin{array}{r}\text { more } \\
\text { than } \\
1,500\end{array}$ & $\begin{array}{l}\text { Bovanenkovo field } \\
\text { on the Yamal } \\
\text { peninsula and } \\
\text { Urengoy area fields }\end{array}$ & Western Russia and Europe & $\begin{array}{l}\text { The Urengoy-Ukhta-Torzhok } \\
\text { line started operations in } \\
2006 \text {. The 1st Bovanenkovo- } \\
\text { Ukhta line started operations } \\
\text { in } 2012 \text {. }\end{array}$ \\
\hline $\begin{array}{l}\text { Soyuz and } \\
\text { Brotherhood } \\
\text { (Urengoy- } \\
\text { Pomary- } \\
\text { Uzhgorod) }\end{array}$ & operating & $\begin{array}{r}\text { more } \\
\text { than } 3.5\end{array}$ & $\begin{array}{r}\text { more } \\
\text { than } \\
2,800\end{array}$ & $\begin{array}{l}\text { West Siberian fields } \\
\text { including Urengoy } \\
\text { area, Russian Urals } \\
\text { fields, and Central } \\
\text { Asia }\end{array}$ & $\begin{array}{l}\text { Western Russia and Europe } \\
\text { via Ukraine }\end{array}$ & $\begin{array}{l}\text { First major natural gas } \\
\text { export lines to Europe, built } \\
\text { and brought online during } \\
\text { the Soviet era. }\end{array}$ \\
\hline $\begin{array}{l}\text { Southern } \\
\text { Corridor } \\
\text { pipelines }\end{array}$ & construction & 2.2 & $\begin{array}{r}\text { Western } \\
\text { route- } \\
550 \\
\text { Eastern } \\
\text { route - } \\
1,010\end{array}$ & $\begin{array}{l}\text { West Siberian fields } \\
\text { including Urengoy } \\
\text { area }\end{array}$ & $\begin{array}{l}\text { Turkey and Europe via } \\
\text { Turkish stream pipeline }\end{array}$ & $\begin{array}{l}\text { Construction on the Western } \\
\text { route began in } 2012\end{array}$ \\
\hline $\begin{array}{l}\text { Turkish stream } \\
\text { - line } 1\end{array}$ & planning & 0.6 & $\begin{array}{r}\text { more } \\
\text { than } 500\end{array}$ & $\begin{array}{l}\text { West Siberian fields } \\
\text { including Urengoy } \\
\text { area }\end{array}$ & Turkey & $\begin{array}{l}\text { Announced completion by } \\
\text { end of } 2016\end{array}$ \\
\hline $\begin{array}{l}\text { Turkish stream } \\
\text { - lines } 2-4\end{array}$ & planning & 1.7 & $\begin{array}{r}\text { more } \\
\text { than } 500\end{array}$ & $\begin{array}{l}\text { West Siberian fields } \\
\text { including Urengoy } \\
\text { area }\end{array}$ & Southeast Europe via Turkey & By 2019 \\
\hline South stream & canceled & 2.2 & $\begin{array}{r}560 \\
\text { (offshore) }\end{array}$ & $\begin{array}{l}\text { West Siberian fields } \\
\text { including Urengoy } \\
\text { aras }\end{array}$ & $\begin{array}{l}\text { Southeast Europe via the } \\
\text { Black Sea }\end{array}$ & $\begin{array}{l}\text { Canceled in late } 2014 \text { and } \\
\text { replaced with Turkish stream }\end{array}$ \\
\hline \multicolumn{7}{|c|}{ Eastern pipelines } \\
\hline TransSakhalin & operating & 0.3 & 500 & $\begin{array}{l}\text { Sakhalin fields } \\
\text { (offshore northern } \\
\text { Sakhalin) }\end{array}$ & $\begin{array}{l}\text { Sakhalin LNG plant, } \\
\text { Prigorodnoye, southern } \\
\text { Sakhalin Island }\end{array}$ & Started operations in 2008 \\
\hline $\begin{array}{l}\text { Sakhalin- } \\
\text { Khabarovsk- } \\
\text { Vladivostok }\end{array}$ & operating & 0.2 & 1,120 & $\begin{array}{l}\text { Sakhalin fields } \\
\text { (offshore northern } \\
\text { Sakhalin) }\end{array}$ & $\begin{array}{l}\text { Eastern Russia with potential } \\
\text { exports to Asia via proposed } \\
\text { Vladivostok LNG or new } \\
\text { pipelines }\end{array}$ & $\begin{array}{l}\text { Started operations in } 2011 . \\
\text { Expandable to } 1.1 \text { Tcf per } \\
\text { year with additional } \\
\text { compression. }\end{array}$ \\
\hline $\begin{array}{l}\text { Power of } \\
\text { Siberia, phase } \\
1 \text { ("Eastern } \\
\text { route" for } \\
\text { exports to } \\
\text { China) }\end{array}$ & construction & 1.3 & 1,370 & $\begin{array}{l}\text { Chayodinsk field, } \\
\text { Yakutia region, } \\
\text { East Siberia }\end{array}$ & $\begin{array}{l}\text { Eastern Russia and } \\
\text { northeast China }\end{array}$ & Announced start of late 2017 \\
\hline $\begin{array}{l}\text { Power of } \\
\text { Siberia } \\
\text { (complete } \\
\text { route) }\end{array}$ & construction & 2.2 & 2,490 & $\begin{array}{l}\text { East Siberian fields } \\
\text { including } \\
\text { Chayodinsk in } \\
\text { Yakutia region and } \\
\text { Kovytka in Irkutsk } \\
\text { region }\end{array}$ & $\begin{array}{l}\text { Eastern Russia and } \\
\text { northeast China, with } \\
\text { potential additional exports to } \\
\text { Asia via proposed Vladivostok } \\
\text { LNG or new pipelines }\end{array}$ & 2019 or later \\
\hline $\begin{array}{l}\text { AltaiWestern } \\
\text { route }\end{array}$ & planning & 1.1 & 1,620 & $\begin{array}{l}\text { West Siberian fields } \\
\text { including Urengoy } \\
\text { arad }\end{array}$ & China & 2020 or later \\
\hline
\end{tabular}

Reference: https://www.eia.gov/beta/international/analysis.cfm?iso=RU, 2015 
Image 1: Russia’s Oil and Natural Gas Pipelines

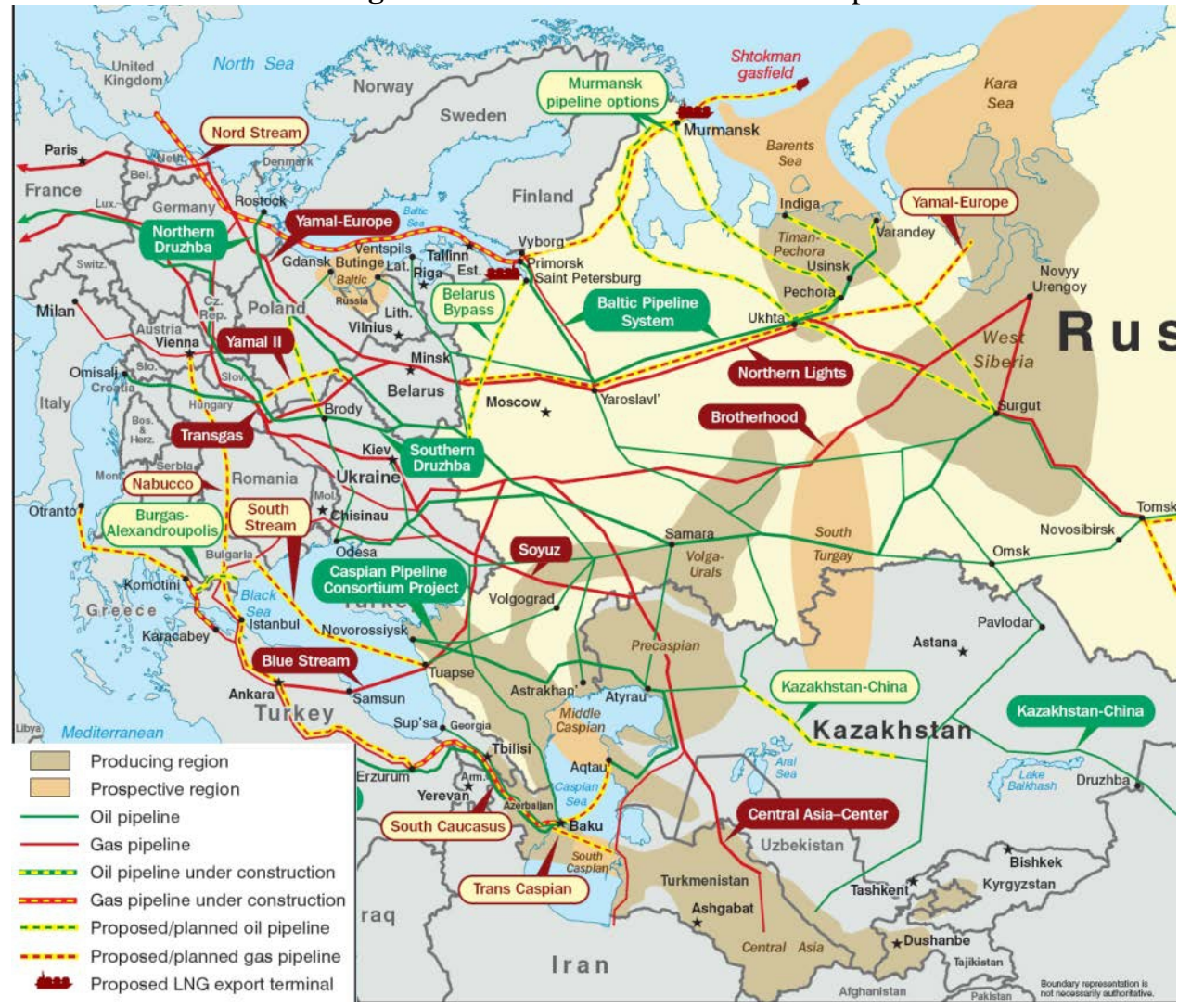

Reference:https://www.google.com.tr/search?q=russia+energy+corridors\&rlz=1C2AV NG_enTR637TR637\&biw=, 19.02.2016.

Image 2: EU Gas Dependence on Russia

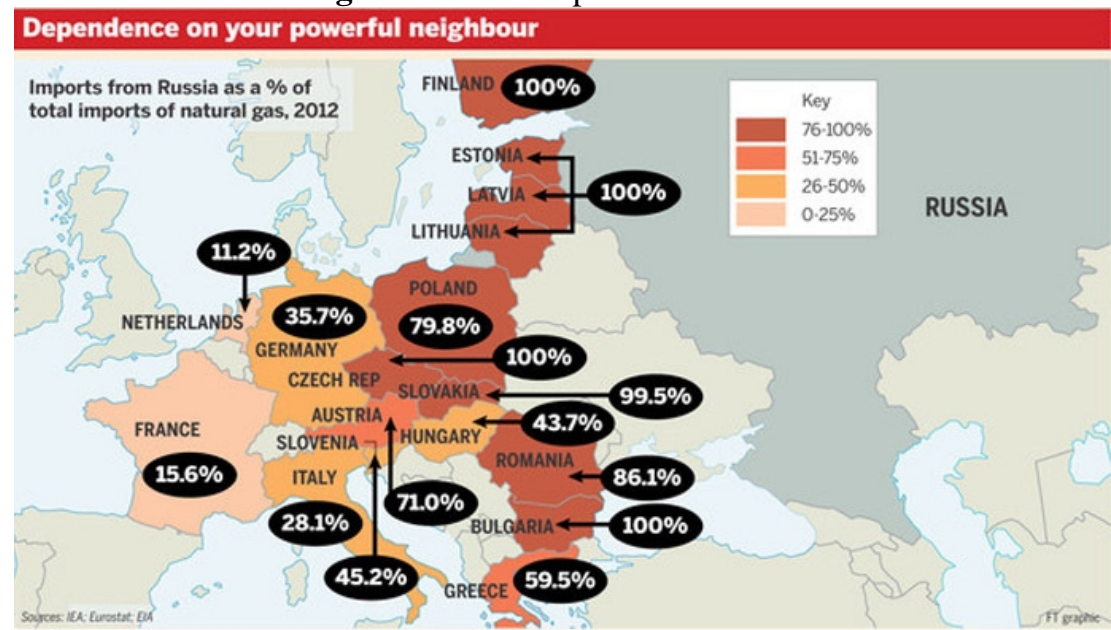

Reference:http://www.zerohedge.com/news/2014-09-10/russian-retaliation-beginsgazprom-limiting-eu-gas-cuts-poland-supplies-20-past-two-, 2016 